\title{
Cytochemical study of Rhodnius neglectus and Rhodnius prolixus salivary gland cells (Hemiptera, Triatominae)
}

\author{
Ana C. B. M. Anhê, Ana P. M. Lima-Oliveira \& Maria T. V. Azeredo-Oliveira
}

Departamento de Biologia, Instituto de Biociências, Letras e Ciências Exatas - Universidade Estadual Paulista “Júlio de Mesquita Filho” - IBILCE/UNESP, São José do Rio Preto, SP, Brazil. (Corresponding author: anacbanhe@yahoo.com.br)

\begin{abstract}
Triatomines are hematophagous bugs of medical interest in South and Central America, where they may act as invertebrate hosts of the hemoflagellate protozoa Trypanosoma cruzi (the causative of Chagas' disease) and Trypanosoma rangeli (Tejera, 1920). Triatomines of Rhodnius genus have salivary gland formed by two close and independent units: the principal and the accessory. This gland secretes saliva that abounds in substances that facilitate and permit feeding. Despite this importance, there are few reports on its cytochemistry. In purpose of amplifying this understanding, in this work it was investigated the nuclear structures (chromatin and nucleolar corpuscles) of salivary gland cells of Rhodnius neglectus (Lent, 1954) and Rhodnius prolixus (Stål, 1859). The salivary glands were removed from adult insects, fixed and submitted to different cytochemical methods: lacto-acetic orcein, silver ion impregnation, Feulgen reaction, Toluidine Blue, Variant method of critical electrolyte concentration and C-banding. The results evidenced predominance of binucleated cells, with bulky and polyploid nucleus, decondensed chromatin and a large nucleolar area. In addition, cytoplasmic metachromasy and a clear association between nucleolar and heterochromatic corpuscles were observed. Such characteristics were associated with intense synthesis activity to produce saliva. Besides, the heterochromatic corpuscles observed with C Banding permitted the differentiation of sexes and species.
\end{abstract}

KEYWORDS. Gland, morphology, chromatin, nucleolus, nucleus.

RESUMO. Estudo citoquímico de células da glândula salivar de Rhodnius neglectus e Rhodnius prolixus (Hemiptera, Triatominae) Os triatomíneos são insetos hematófagos que apresentam interesse médico nas América do Sul e Central por serem hospedeiros invertebrados dos protozoários hemoflagelados Trypanosoma cruzi (agente etiológico da doença de Chagas) e Trypanosoma rangeli (Tejera, 1920). Os triatomíneos do gênero Rhodnius possuem glândula salivar formada por duas unidades próximas e independentes: a principal e a acessória. Esta glândula secreta uma saliva que contém substâncias que facilitam e permitem a hematofagia. Entretanto, apesar da sua importância, poucos estudos realizaram sua análise citoquímica. No propósito de ampliar esse entendimento, neste trabalho foram investigadas as estruturas nucleares (cromatina e corpúsculos nucleolares) das células da glândula salivar de Rhodnius neglectus (Lent, 1954) e Rhodnius prolixus (Stål, 1859). As glândulas foram removidas de insetos adultos, fixadas e submetidas a diferentes métodos citoquímicos: Orceína Lacto-Acética, Impregnação por Íons de Prata, Reação de Feulgen, Azul de Toluidina, Variante da Concentração Eletrolítica Crítica e Bandamento C. Os resultados evidenciaram predomínio de células binucleadas, com núcleos volumosos e poliplóides, cromatina descondensada e uma grande área nucleolar. Além disso, foi observada metacromasia citoplasmática e uma clara associação entre os corpúsculos nucleolares e heterocromáticos. Tais características foram associadas às atividades de intensa síntese proteica para a produção de saliva. Além disso, os corpúsculos heterocromáticos observados no Bandamento C permitiram a diferenciação dos sexos e das espécies.

PALAVRAS-CHAVE. Glândula, morfologia, cromatina, nucléolo, núcleo.

Triatomines are vector of Trypanosoma cruzi (Chagas, 1909), the etiological agent of Chagas disease. In Latin America, it has been estimated that there are 15-17 million people infected and 90-100 million are exposed to infection (COURA \& Borges-Pereira, 2010). Rhodnius genus is also vector of Trypanosoma rangeli (Tejera, 1920), a protozoon transmitted by the bite and apparently harmless to humans. It is pathogenic to the insect vector (HECKER et al., 1990).

Triatomines are hematophagous insects throughout the lifecycle. During the blood feeding (probing and engorgement phases), saliva is released (SoAres et al., 2006). It is enriched with molecules that antagonize host's hemostatic, inflammatory and immunological responses, facilitating feeding (Ribeiro \& FrancischetTI, 2003). This saliva, in association with cryptic behavior, nocturnal habits of triatomines and mechanical adaptations of mouthparts, allows few perceivable bites thus enabling a successful blood meal.

Saliva is produced by a salivary gland formed by two close and independent units: the larger is reddish and elongated (principal unit) and the smaller is round and translucent (accessory unit) (BAPTIST, 1941; REIS et al., 2003). Ultrastructural analysis showed abundant endoplasmic reticulum, mitochondria and microvilli in the apical plasma membrane domain, thus enlarging the membrane area available for saliva secretion (MeIRELLES et al., 2003; ReIs et al., 2003). In addition, an intense acid phosphatase activity was found in nucleolus, suggesting the activity of this enzyme during rRNA molecule transcription (ANHÊ et al., 2007).

Recently, Rocha et al. (2010) developed a primary culture of Rhodnius prolixus (Stål, 1859) salivary gland cells. Three types of cells were identified, mostly binucleated. In addition, some secretion vesicles were observed budding from duct cells, suggesting a possible secretory role of this structure.

Despite its importance, the cytochemical characteristics of this gland are little known. So, the purpose of this work is to describe nuclear structures (chromatin 
and nucleolus) of salivary gland cells of two species of Rhodnius: Rhodnius neglectus (Lent, 1954) and Rhodnius prolixus. Besides, some aspects that allow comparing and differentiating sexes and species are described.

\section{MATERIAL AND METHODS}

Salivary glands of $R$. neglectus and $R$. prolixus of both sexes were used in this study. They were from Frutal (state of Minas Gerais, Brazil) (R. neglectus) and Colombia (R. prolixus) and were obtained from the Insectary of the Araraquara Special Health Service, organ of the São Paulo University (Araraquara, state of São Paulo, Brazil). Forty newly-emerged adults (twenty males and twenty females) of each species were analyzed. They fed on mice and were dissected seven days after feeding.

For cytochemical characterization, triatomines were dissected in Demerec solution. Salivary glands were fixed in acetic acid (45\%) and lactic acid (50\%), squashed and submitted to the following cytochemical methods: lactoacetic orcein (DE VAIO et al., 1985 - with modifications), silver ion impregnation (Howell \& BLACK, 1980 - with modifications), Feulgen reaction (MeLLo \& VIDAL, 1980 - with modifications), Toluidine Blue, Variant method of critical electrolyte concentration (CEC) (Mello et al., 1993 - with modifications) and C-banding (SUMNER, 1972 - with modifications). The preparations were examined with a photomicroscope and photographed, after which the negatives were developed and printed in specialized laboratories.

\section{RESULTS}

The techniques described nuclear structures of salivary gland cells of both sexes of $R$. neglectus (Figs 1-12) and $R$. prolixus (Figs 13-24). Bulky and polyploid nuclei were observed with a predominance of binucleated cells.

Orcein (Figs 1, 7, 13, 19), Feulgen reaction (Figs 3, 9, 15, 21), Variant of CEC (Figs 5, 11, 17, 23) and C-banding (Figs 6, 12, 18, 24), techniques specific to chromatin, highly stained euchromatin as a thin granulation dispersed in the nucleus (decondensed chromatin). A unique heterochromatic corpuscle was observed just on males (Figs 1, 3, 4, 6, 13, 15, 16, 18). However, the technique of $\mathrm{C}$ Banding showed, in $R$. prolixus, a lot of heterochromatic corpuscles in both sexes (Figs 18, 24). Light halos were also observed in association with heterochromatin (characteristic of nucleolar corpuscles). These halos were highly stained by silver ion impregnation, specific for nucleolar corpuscles. They were small, circular and numerous: about 50 corpuscles in both sexes of $R$. prolixus, while in $R$. neglectus were observed about 60 in females and 30 in males.

Variant of CEC showed blue nucleolar corpuscles surrounded by green chromatinic halos (Figs 5, 11, 17, 23). A solution of Toluidine Blue (without magnesium chloride $-\mathrm{MgCl}_{2}$ ) was used for the control technique, in which cells showed a metachromatic blue in all components (nuclear and cytoplasmic ones) (Figs 4, 10, 16, 22). Cytoplasm was mainly stained by the techniques of silver ion impregnation (Figs 2, 6, 14, 20), Toluidine Blue (Figs 4, 10, 16, 22) and Variant of CEC (Figs 5, 11, 17, 23).

\section{DISCUSSION}

Cytochemical techniques evidenced some characteristics of nuclei (chromatin and nucleolus) of salivary gland cells of $R$. neglectus and $R$. prolixus (both sexes). They showed a predominance of two bulky and polyploid nuclei in each cell, as observed in salivary gland of Triatoma infestans (Klug, 1834) and Panstrongylus megistus (Burmeister, 1835) (ANHÊ \& Azeredo-Oliveira, 2008). According to BARTH (1954), this increasing of nuclear mass may provide the intense metabolism, essential to accelerate and regulate cellular regeneration after saliva secretion. Polyploidy is a common phenomenon in many insect tissues, as midgut, epidermis, fat body, Malpighian tubules, trachea and ovary follicle (EDGAR \& ORR-WEAVER, 2001). Binucleated cells are described for salivary gland of other Hemiptera, as Cimex hemipterus (Fabricius, 1803) (SERRÃo et al., 2008), Rhynocoris marginatus (Fabricius, 1794) (Kumar \& SahayaraJ, 2012), Supputius cincticeps (Stal, 1860) (De Castro et al., 2013) and Podisus nigrispinus (Dallas, 1851) (MARTínez et al., 2014).

Orcein (for proteins-DNA complexed), Feulgen reaction (specific to DNA) and C-Banding (for constitutive heterochromatin), which are specific for chromatin staining, showed a predominance of decondensed chromatin, as already described for salivary glands of other Hemiptera (Lacombe, 1999; Anhê \& Azeredo-Oliveira, 2008; Serrão et al., 2008; Kumar \& SAhayaraj, 2012; De Castro et al., 2013; MARTínEZ et al., 2014). These characteristics indicated increasing nuclear mass in relation to the cytoplasm and increasing metabolic activity (Li et al., 2007), necessary to produce saliva.

In addition, techniques permitted the differentiation of sexes, since just on males a unique heterochromatic corpuscle was observed. PANZERA et al. (1992) proposed a way of naming the sex chromosomes according to their C-heterochromatin: the $\mathrm{Y}$ is the heterochromatic sex chromosome. Thus, the heterochromatic corpuscle observed just on males, probably, corresponds to the $\mathrm{Y}$ chromosome and, so, justify its absence in females. Similar results were found in other species of triatomines. In $T$. infestans, a heterochromatic body called chromocenter (Mello, 1971, 1975) is characteristic of males (AnHê \& Azeredo-Oliveira, 2008) and corresponds to the packed three largest autosomes and the sex chromosome (SolarI, 1979; Panzera et al., 1992; Perez et al., 1997). In P. megistus, just males presented a heterochromatic corpuscle (AnHÊ \& AZEREdo-OliveIRA, 2008), which is characteristic of $\mathrm{Y}$ chromosome and can also be present in X1 and X2 chromosomes (TARTAROTTI \& AzEREDO-OliveIRA, 1999). In addition, C-Banding permitted the differentiation of the 

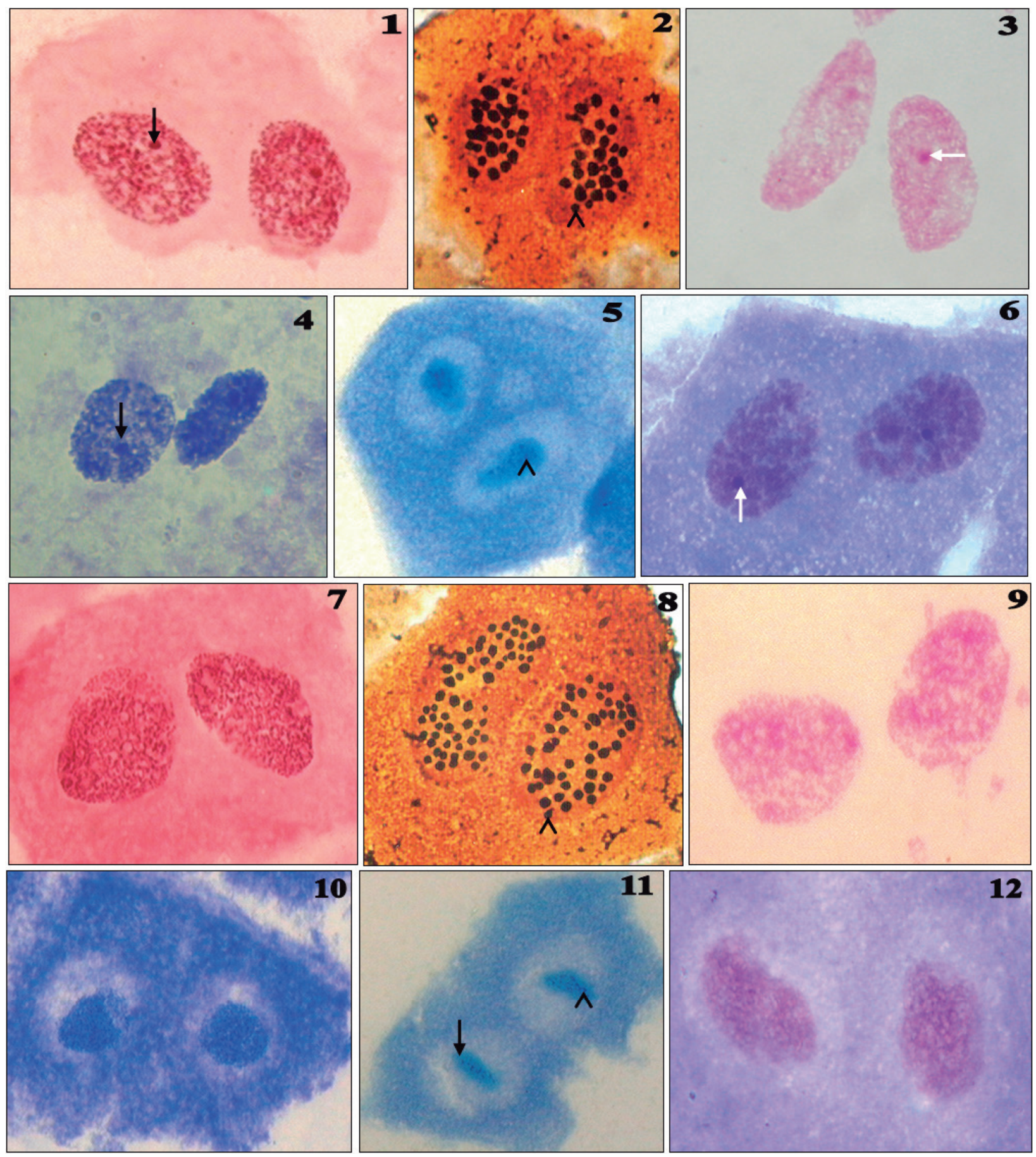

Figs 1-12, Polyploid nuclei of salivary gland of males (1-6) and females (7-12) of Rhodnius neglectus (Lent, 1954), stained by the following cytochemical methods: 1, 7, lacto-acetic orcein; 2, 8, silver ion impregnation; 3, 9, Feulgen reaction; 4, 10, Toluidine Blue; 5, 11, Variant method of critical electrolyte concentration; 6, 12, C-banding. Arrows indicate heterochromatic corpuscles and arrowhead the nucleolar ones. Notice the presence of heterochromatic corpuscle on males $(1,3,4,6)$. Magnifications: $1344 x$.

species of Rhodnius genus, since just R. prolixus showed a lot of heterochromatic corpuscles.

For nucleolar staining, silver ion impregnation was used. This technique stains proteins present in nucleolar bodies during interphase, as nucleolin (C23) and numatrin (B23) (Ochs et al., 1983). The technique evidenced, in both species, numerous and small nucleolar corpuscles representing a large nucleolar area. Since fully active nucleoli are large (NANYA \& Bicudo, 1995; CARMo-FonseCA et al., 2000), it can be suggested that this large nucleolar area was related with high cellular metabolism. Large nucleolar area was described for salivary glands of other Hemiptera (Lacombe, 1999; Anhê \& Azeredo-Oliveira, 2008; Serrão et al., 2008; Kumar \& Sahayaraj, 2012; De CASTRo et al., 2013; MARTínez et al., 2014). A previous study showed acid phosphatase activity in salivary gland cells of 

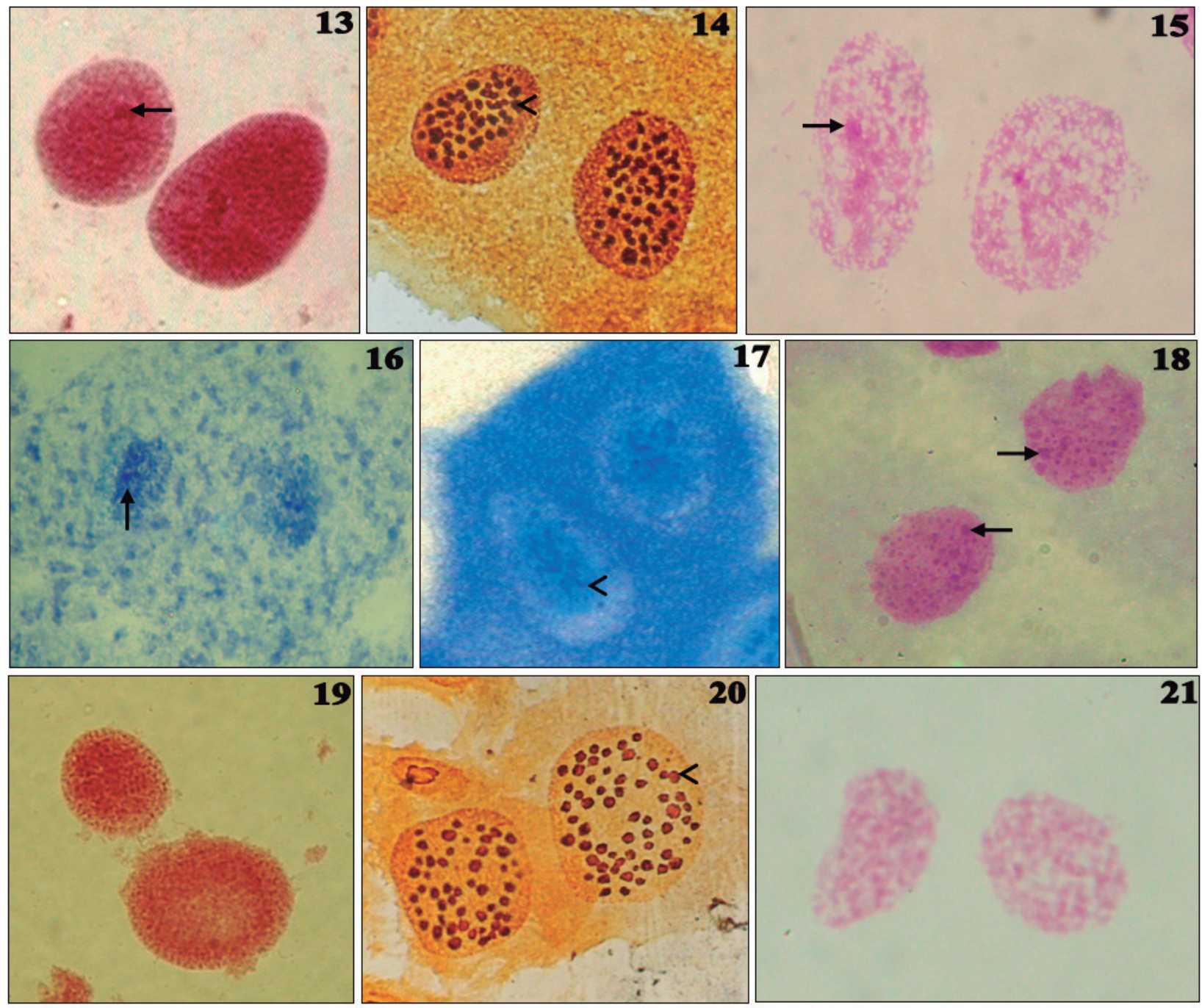

21
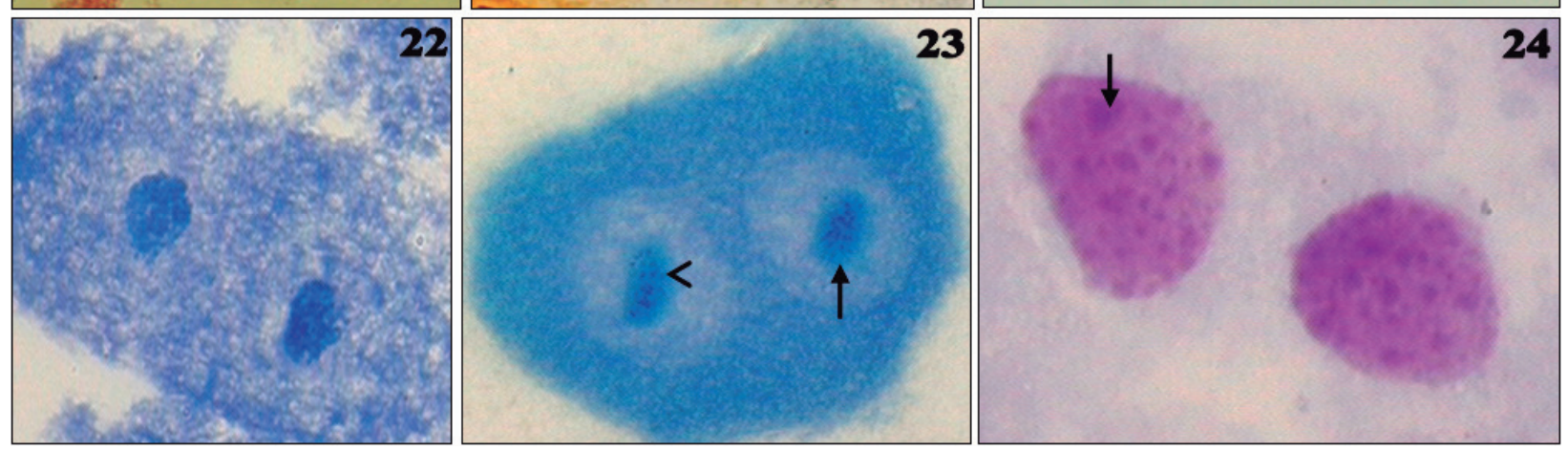

Figs 13-24, Polyploid nuclei of salivary gland of males (13-18) and females (19-24) of Rhodnius prolixus (Stål, 1859), stained by the following cytochemical methods: 13, 19, lacto-acetic orcein; 14, 20, silver ion impregnation; 15, 21, Feulgen reaction; 16, 22, Toluidine Blue; 17, 23, Variant method of critical electrolyte concentration; 18, 24, C-banding. Arrows indicate heterochromatic corpuscles and arrowhead the nucleolar ones. Notice the presence of heterochromatic corpuscle on males $(13,15,16,18)$ and some on females (1). Magnifications: 1344x.

R. neglectus and R. prolixus. The most intense activity was found in chromatin and in nucleolus (ANHê et al., 2007).

For both nucleolar and chromatic staining, the technique of Variant of CEC was used (Mello et al., 1993). In this technique, slides were first treated with a Toluidine Blue solution, which stains DNA and RNA in blue (control technique). After, the material was submitted to a magnesium chloride $0.05 \mathrm{M}$ solution until the metachromasy of DNA be abolished and it stained in green, while RNA continues bluish. So, the results showed small nucleolar corpuscles (bluish) surrounded by halos of heterochromatin (greenish), which confirmed association between DNA and RNA, proposed by other techniques utilized. This very close association, classically observed in other tissues and organisms, evidences the functional relationship between these structures, very important to the maintenance of nucleolar architecture (CARMO-FonSECA et al., 2000). Staining with just Toluidine Blue was employed as control 
for the technique, when DNA and RNA showed the same metachromatic blue coloration.

Besides, different forms and sizes of nuclei were observed, which could be related to the saliva secretion. According to BARTH (1954), there are four to six phases, including transport of substances, secretion of the saliva and cell regeneration. BARTH (1954) and LACOMBE (1999) also observed that the insect nutrition changes the cell morphology. To avoid this variable, in this study the insects were dissected seven days after feeding.

Cytoplasmic staining evidenced by the techniques of silver ion impregnation, Toluidine blue and variant of CEC indicated the presence of cytoplasmic RNA (mRNA, tRNA and rRNA). This suggested the high protein synthesis in the gland, necessary to produce saliva.

Thus, these results clearly suggest that polyploid binucleated cells with bulky nuclei, large nucleoli and the high metachromasy in cytoplasm were related to the intense activity of salivary gland cells. These characteristics reflect the high protein synthesis, necessary to the composition of saliva and contribute to a successful blood feeding. In addition, chromatin staining techniques enable to differentiate the sexes and the species.

Acknowledgements. The authors thank Dr. José M. Soares Barata, João Luís Molina Gil and João Maurício R. da Silva Filho, director and technicians, respectively, of the Insectary of the Araraquara Special Health Service (SESA), São Paulo Public Health School (Araraquara, $\mathrm{SP})$, for providing the specimens studied. The authors are also grateful to two anonymous reviewers for comments and to Fernanda Ambrogi Barbosa da Luz for language assistance. The financial support of CNPq and FAPESP are gratefully acknowledged.

\section{REFERENCES}

Anhê, A. C. B. \& Azeredo-Oliveira, M. T. V. 2008. Cytochemical characterization of Triatoma infestans and Panstrongylus megistus salivary gland cells (Hemiptera, Reduviidae, Triatominae). Micron 39:1126-1133.

Anhê, A. C. B.; Lima-Oliveira, A. P. M. \& Azeredo-Oliveira, M. T. V. 2007. Acid phosphatase activity distribution in salivary glands of triatomines (Heteroptera, Reduviidae, Triatominae). Genetics and Molecular Research 6(1):197-205.

BAPTIST, B. A. 1941. The morphology and physiology of the salivary glands of Hemiptera-Heteroptera. Quarterly Journal of Microscopical Science 82:91-139.

BARTH, R. 1954. Estudos anatômicos e histológicos sobre a subfamília Triatominae (Heteroptera, Reduviidae). IV. Parte: O complexo das glândulas salivares de Triatoma infestans. Memórias do Instituto Oswaldo Cruz 52:517-585.

Carmo-Fonseca, M.; Mendes-Soares, L. \& Campos, I. 2000. To be or not to be in nucleolus. Nature Cell Biology 2:E107-E112.

Coura, J. R. \& Borges-Pereira, J. 2010. Chagas disease: 100 years after its discovery. A systemic review. Acta Tropica 115(1-2):5-13.

De Castro, A. A.; Canevari, G. C.; Pikart, T. G.; Ribeiro, R. C.; Serrão, J. E.; ZanunCio, T. V. \& ZANunCio, J. C. 2013. Salivary Gland Histology of the Predator Supputius cincticeps (Heteroptera: Pentatomidae). Annals of the Entomological Society of America 106(2):273-277.

De Vaio, E. S.; Crucci, B.; Castagnino, A. M.; Franca, M. E. \& Martinez, M. E. 1985. Meiotic differences between three triatominae species (Hemiptera, Reduviidae). Genetica 67:185-191.

Edgar, B. A. \& Orr-Weaver, T. L. 2001. Endoreplication cell cycles: more for less. Cell 105:297-306.

Hecker, H.; Schwarzenbach, M. \& Rudin, W. 1990. Development and interactions of Trypanosoma rangeli in and with the reduviid bug,
Rhodnius prolixus. Parasitology Research 76:311-318.

HowelL, W. \& BLACK, D. A. 1980. Controlled silver staining of nucleolus organizer regions with protective colloidal developer: a 1-step method. Experientia 36:1014-1015.

Kumar, S. M. \& SahayaraJ, K. 2012. Gross morphology and histology of head and salivary apparatus of the predatory bug, Rhynocoris marginatus. Journal of Insect Science 12(19):1-12.

Lacombe, D. 1999. Anatomia e Histologia das Glândulas Salivares nos Triatomíneos. Memórias do Instituto Oswaldo Cruz 94(4):557-564.

Li, B.; CARey, M. \& Workman, J. L. 2007. The role of chromatin during transcription. Cell 128:707-719.

Martínez, L. C.; Fialho, M. C. Q.; Zanuncio, J. C. \& Serrão, J. E. 2014. Ultrastructure and cytochemistry of salivary glands of the predator Podisus nigrispinus (Hemiptera: Pentatomidae). Protoplasma 251:535-543.

Meirelles, R. M.; Rodrigues, I. S.; Steindel, M. \& Soares, M. J. 2003. Ultrastructure of the salivary glands of Rhodnius domesticus Neiva \& Pinto, 1923 (Hemiptera: Reduviidae). Journal of Submicroscopic Cytology and Pathology 35(2):199-207.

Mello, M. L. S. 1971. Nuclear behavior in the Malpighian tubes of Triatoma infestans (Reduv., Hemiptera). Cytologia 36(1):42-49. .1975. Feulgen-DNA values and ploidy degrees in the Malpighian tubes of some triatomids. Revista Brasileira de Pesquisas Médicas e Biológicas 8(2):101-107.

Mello, M. L. S. \& Vidal, B. C. 1980. Práticas de Biologia Celular. Campinas, Edgard Blucher. 71p.

Mello, M. L. S.; Vidal, B. C.; Dantas, M. M. \& Monteiro, A. L. P. 1993. Discrimination of the nucleolus by a critical electrolyte concentration method. Acta Histochemica et Cytochemica 26:1-3.

NANYA, S. \& Bicudo, H. E. M. C. 1995. Variation of nucleolar area in fat tissue of Drosophila mulleri during development. Cytobios 81:73-86.

Ochs, R.; Lischwe, M.; O’Leary, P. \& Busch, H. 1983. Localization of nucleolar phosphoproteins B23 and C23 during mitosis. Experimental Cell Research 146(1):139-149.

Panzera, F.; Alvarez, F.; Sanchez-Rufas, J.; Perez, R.; Suja, J. A.; Scvortzoff, E.; Dujardin, J. P.; Estramil, E. \& Salvatella, R. 1992. C-heterochromatin polymorphism in holocentric chromosomes of Triatoma infestans (Hemiptera: Reduviidae). Genome 35:1068-1074.

Perez, R.; Panzera, F.; Page, J.; Suja, J. A. \& Rufas, J. S. 1997. Meiotic behaviour of holocentric chromosomes: orientation and segregation of autosomes in Triatoma infestans (Heteroptera). Chromosome Research 5(1):47-56.

Reis, M. M.; Meirelles, R. M. S. \& Soares, M. J. 2003. Fine structure of the salivary glands of Triatoma infestans (Hemiptera: Reduviidae). Tissue Cell 35:393-400.

Ribeiro, J. M. C. \& Francischetti, M. B. 2003. Role of arthropod saliva in blood feeding: sialomeand post-sialome perspectives. Annual Review of Entomology 48:73-88.

Rocha, F. F.; Araújo, R. N.; Silva, L. M.; Gontijo, N. F. \& Pereira, M. H. 2010. Primary culture of Rhodnius prolixus (Hemiptera: Reduviidae) salivary gland cells. Memórias do Instituto Oswaldo Cruz 105(2):132-136.

Serrão, J. E; Castrillon, M. I.; Santos-Mallet, J. R.; Zanuncio, J. C. \& Gonçalves, T. C. M. 2008. Ultrastructure of the Salivary Glands in Cimex hemipterus (Hemiptera: Cimicidae). Journal of Medical Entomology 45(6):991-999.

Soares, A. C.; Carvalho-Tavares, J.; Gontijo, N. F.; Dos Santos, V. C.; Teixeira, M. M. \& Pereira, M. H. 2006. Salivation pattern of Rhodnius prolixus (Reduviidae; Triatominae) in mouse skin. Journal of Insect Physiology 52:468-472.

Solari, A. J. 1979. Autosomal synaptonemal complexes and sex chromosomes without axes in Triatoma infestans (Reduviidae; Hemiptera). Chromosoma 72:225-240.

SuMNER, A. T. 1972. A simple technique for demonstrating centromeric heterochromatin. Experimental Cell Research 75:304-306.

Tartarotti, E. \& Azeredo-Oliveira, M. T. V. 1999. Heterochromatin patterns in triatomines of the genus Panstrongylus. Cytobios 99:13122. 